\title{
Rapid and sensitive spectrophotometric determination of trace amounts of iron(III) using leuco Xylene cyanol FF
}

Received: 22 February 2003 / Revised: 1 May 2003 / Accepted: 1 May 2003 / Published online: 25 June 2003

(C) Springer-Verlag 2003

\begin{abstract}
A new, simple, sensitive, and reliable method is presented for the rapid spectrophotometric determination of trace amounts of iron(III) using leuco Xylene cyanol FF. The method is based on the oxidation of leuco Xylene cyanol FF (LXCFF) to its blue form of xylene cyanol FF by iron(III) in sulfuric acid medium ( $\mathrm{pH}$ 2.0-3.0), the absorbance of the formed dye is measured in an acetate buffer medium ( $\mathrm{pH} 2.8-4.4)$ at $615 \mathrm{~nm}$. The method obeys Beer's law over a concentration range of $0.15-0.9 \mu \mathrm{g} \mathrm{mL}^{-1}$ iron, having a molar absorptivity of $5.6 \times 10^{4} \mathrm{~L} \mathrm{~mol}^{-1} \mathrm{~cm}^{-1}$ and a Sandell's sensitivity of $0.0001 \mu \mathrm{g} \mathrm{cm}^{-2}$. The optimum reaction conditions and other analytical parameters have been evaluated. The developed method has been successfully applied to the determination of iron in water, soil, industrial effluent, plant material, pharmaceutical preparations, synthetic mixtures, and aluminum alloys.
\end{abstract}

Keywords Spectrophotometry · Iron(III) determination . Leuco Xylene cyanol FF

\section{Introduction}

Iron which is one of the cornerstones of progress in any society, is also an essential nutrient required by all organisms. It is present in human body in amounts greater than that of any trace element; its concentration and physiological impacts depending on the state of health, nutrition, age and sex. Iron is widely distributed in foods of plant and animal tissues [1]. The determination of trace elements, particularly heavy metals such as iron, has received increasing attention in pollution studies. In filtered

\footnotetext{
T. N. Kiran Kumar

Department of Chemistry, Government College for Women, 571401 Mandya, India
}

H. D. Revanasiddappa (®)

Department of Chemistry, University of Mysore,

Manasagangothri, 570006 Mysore, India

e-mail: hdrevanasiddappa@yahoo.com samples of oxygenated surface waters iron concentrations seldom reach $1 \mathrm{mg} \mathrm{L}^{-1}$. Some ground waters and acid surface drainage may contain considerably more iron. Iron in water can cause staining of laundry and porcelain. A bittersweet astringent taste is detectable by some persons at levels above $1 \mathrm{mg} \mathrm{L}^{-1}$ [2].Thus, the determination of trace amounts of iron is important. Flame, and graphite-furnace atomic absorption spectrometry $[3,4,5,6,7]$ are the most commonly used techniques for iron determination. But these methods are disadvantageous in terms of cost and instruments used in routine analysis. AAS is often lacking in sensitivity and affected by matrix conditions of samples such as salinity. Extractive methods $[8,9,10,11]$ are highly sensitive but are generally lacking in simplicity. Spectrophotometry is essentially a trace analytical technique and is one of the most powerful tools in chemical analysis. A wide variety of reagents have been proposed for the spectrophotometric determination of iron(III) $[12,13,14,15$, $16,17,18,19,20,21,22]$, among them, 1,10-phenanthroline is considered as most selective and sensitive reagent for the iron determination [2]. But this method suffers from interference of foreign ions, stability, simplicity and range of determination. The determination of trace amounts of iron is important in studies of biological processes and for industrial purposes; development of a simple, rapid and sensitive spectrophotometric method is highly desirable.

The aim of this study is to develop a simple, cost-effective, reliable, and sensitive spectrophotometric method for the determination of trace amounts of iron using leuco Xylene cyanol FF as a new reagent. The developed method has been successfully applied to the determination of iron in water, soil, industrial effluents, plant materials, pharmaceutical preparations, synthetic mixtures, and aluminum alloys.

\section{Experimental}

Apparatus

Jasco (Model UVIDEC-610) spectrophotometer with $1 \mathrm{~cm}$ matched glass cells was used for all absorbance measurements. The $\mathrm{pH}$ measurements were made with an Elico (Model IL-610) digital pH meter. 
Reagents

All chemicals used were of analytical reagent grade, and distilled water was used throughout the study.

Standard Fe(III) solution ( $\left.1 \mathrm{mg}^{\mathrm{mL}} \mathrm{L}^{-1}\right)$

Prepared by dissolving $0.8635 \mathrm{~g}$ ferric alum, $\mathrm{FeNH}_{4}\left(\mathrm{SO}_{4}\right)_{2} .12 \mathrm{H}_{2} \mathrm{O}$, in water containing $0.5 \mathrm{~mL}$ conc. $\mathrm{H}_{2} \mathrm{SO}_{4}$ and diluting to volume with water in a $100 \mathrm{~mL}$ volumetric flask. A working standard solution was prepared by an appropriate dilution of the standard solution as and when required.

\section{Leuco Xylene cyanol FF (LXCFF, 0.1\%)}

Prepared by dissolving $100 \mathrm{mg}$ of Xylene cyanol FF (BDH, Poole, England) in $25 \mathrm{~mL}$ of water containing $30 \mathrm{mg}$ zinc dust and $2 \mathrm{~mL}$ of $1 \mathrm{~mol} \mathrm{~L}^{-1}$ acetic acid, stirred well and kept aside for $20 \mathrm{~min}$, then the resulting solution was diluted with $100 \mathrm{~mL}$ water (filter if necessary). This reagent was stable for 60 days.

Sulfuric acid. $0.005 \mathrm{~mol} \mathrm{~L}^{-1}$.

\section{Acetate buffer ( $p H 4)$}

Prepared by dissolving $13.6 \mathrm{~g}$ of sodium acetate trihydrate in $80 \mathrm{~mL}$ water. Solution $\mathrm{pH}$ was adjusted to 4.0 with acetic acid, and the mixture was diluted to $100 \mathrm{~mL}$ with water.

Procedure

General procedure for the determination of iron(III)

An aliquot of a sample solution containing 1.5 to $9 \mu \mathrm{g}$ of iron(III) was transferred into a series of $10 \mathrm{~mL}$ calibrated flasks. Then, $0.5 \mathrm{~mL}$ each of the $0.005 \mathrm{~mol} \mathrm{~L}^{-1} \mathrm{H}_{2} \mathrm{SO}_{4}$ and $0.1 \%$ LXCFF were added to it, and the mixture was kept in a water bath $\left(90^{\circ} \mathrm{C}\right)$ for $10 \mathrm{~min}$; cooled to room temperature $\left(27 \pm 2^{\circ} \mathrm{C}\right)$, and the contents were diluted up to the mark with acetate buffer of $\mathrm{pH} 4$ and mixed well. The absorbance of the formed dye was then measured at $615 \mathrm{~nm}$ against the reagent blank prepared in the same manner without iron(III).

\section{Results and discussion}

Iron(III) quantitatively oxidized leuco Xylene cyanol FF into its blue-colored Xylene cyanol FF dye in sulfuric acid medium (pH 1.6-2.8) in a boiling water bath $\left(\sim 90^{\circ} \mathrm{C}\right.$ for $10 \mathrm{~min})$, the resulting colored dye having a maximum absorption at $615 \mathrm{~nm}$ in an acetate buffer medium $(\mathrm{pH} 2.8$ 4.4). The reagent blank had negligible absorbance at this wavelength. The absorption spectrum of the colored dye formed is depicted in Fig. 1.

\section{Effects of the acidity and temperature}

The oxidation of LXCFF by iron(III) was studied in different acid media. Of the various acids (sulfuric, hydrochloric and phosphoric) studied, sulfuric acid was found to be the best acid for the system. Constant absorbance readings were obtained in the range of $0.1-1.0 \mathrm{~mL} 0.005 \mathrm{~mol} \mathrm{~L}^{-1}$ sulfuric acid (or $\mathrm{pH}$ 1.6-2.8). At lower or higher acidity, the absorbance values gradually decreased. Hence, a volume of $0.5 \mathrm{~mL}$ of $0.005 \mathrm{~mol} \mathrm{~L}^{-1}$ sulfuric acid (or maintained $\mathrm{pH}$ 2) in a total volume of $10 \mathrm{~mL}$, was used in all subsequent work. At room temperature $\left(27 \pm 2{ }^{\circ} \mathrm{C}\right)$, the oxidation reaction is very slow; when the temperature was raised to $90^{\circ} \mathrm{C}$, the reaction was fast, and the absorbance of the dye was maximum and constant. To achieve this, the contents were placed in a water bath, maintained at $90{ }^{\circ} \mathrm{C}$ for $10 \mathrm{~min}$ before dilution to $10 \mathrm{~mL}$.

\section{Effects of the reagent concentration and buffer media}

Under optimum conditions, the reagent concentration of LXCFF leading to maximum color stability was found to be $0.5 \mathrm{~mL}$ of $0.1 \%$ reagent in a total reaction mixture vol-
Fig. 1 Absorption spectra of colored species [Fe(III), $0.5 \mu \mathrm{g} \mathrm{mL}^{-1}$ ] vs. reagent blank (a), and reagent blank vs. distilled water $(b)$

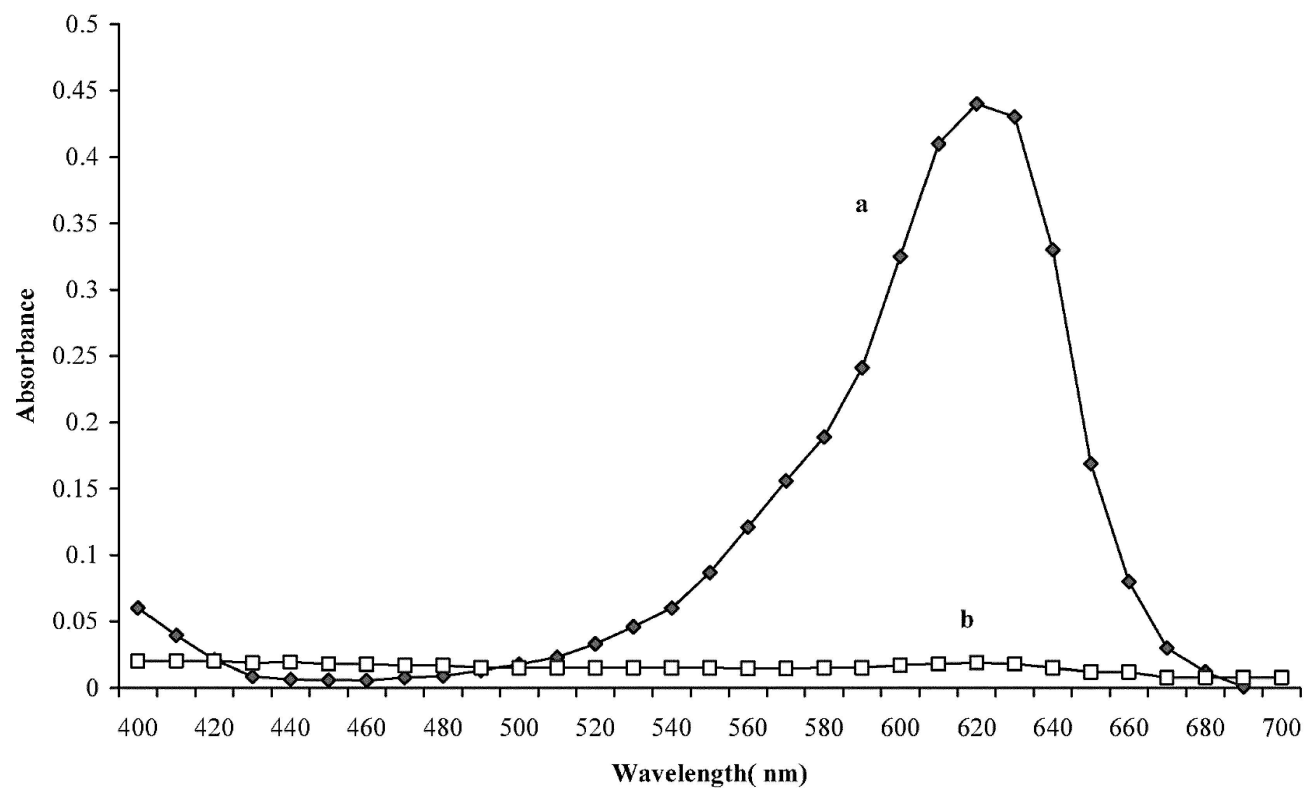


Table 1 Effect of interfering ions on the determination of iron(III) $\left(0.5 \mu \mathrm{g} \mathrm{mL}^{-1}\right)$

\begin{tabular}{ll}
\hline Interferents & $\begin{array}{l}\text { Tolerance limit } \\
\left(\mu \mathrm{g} \mathrm{mL}^{-1}\right)\end{array}$ \\
\hline $\mathrm{Na}^{+}, \mathrm{K}^{+}, \mathrm{Hg}^{2+}, \mathrm{Br}^{-}, \mathrm{Zn}^{2+}, \mathrm{SO}_{4}{ }^{2-} \mathrm{CH}_{3} \mathrm{COO}^{-}, \mathrm{Ca}^{2+}, \mathrm{NO}_{3}^{-}, \mathrm{Mn}^{2+}, \mathrm{Mg}^{2+}, \mathrm{Cl}^{-}$ & $\geq 4000$ \\
$\mathrm{~Pb}^{2+}, \mathrm{NO}_{3}{ }^{-}, \mathrm{Al}^{3+}, \mathrm{Cr}^{3+}, \mathrm{SCN}^{-}, \mathrm{NO}_{2}-\mathrm{Cu}^{2+}, \mathrm{Co}^{2+}, \mathrm{SbO}_{7}{ }^{2-}, \mathrm{MoO}_{4}{ }^{2-}, \mathrm{Ni}^{2+}, \mathrm{Se}^{4+}$ & $\geq 800$ \\
$\mathrm{Fe}^{2+}, \mathrm{Cr}_{2} \mathrm{O}_{7}{ }^{2-}, \mathrm{VO}_{3}^{-}, \mathrm{IO}_{3}{ }^{-}, \mathrm{F}^{-}$, oxalate, tartrate, citrate$, \mathrm{AsO}_{2}^{-}, \mathrm{WO}_{4}{ }^{2-}, \mathrm{Ce}^{4+}$ & $\geq 2$
\end{tabular}

ume of $10 \mathrm{~mL}$. Constant and maximum absorbance values were obtained in the $\mathrm{pH}$ range of 2.8-4.4. An increase of $\mathrm{pH}$ above 4.4 markedly affected the stability and sensitivity of the dye. Color development does not take place below $\mathrm{pH} 2.8$. Hence, this $\mathrm{pH}$ value was maintained by using acetate buffer of $\mathrm{pH} 4$, and the same buffer solution was used as a diluting solvent for the best results. The colored dye formed is stable for more than a week.

\section{Effect of interfering ions}

The effect of various foreign ions at $\mu \mathrm{g} \mathrm{mL}^{-1}$ levels on the determination of iron(III) was studied. The tolerance limits of interfering species were established at those concentrations that do not cause more than $\pm 2 \%$ error in absorbance values of iron(III) at $0.5 \mu \mathrm{g} \mathrm{mL}^{-1}$. Tolerance limits of foreign ions are listed in Table 1 . The oxidizing agents such as $\mathrm{Cr}(\mathrm{VI}), \mathrm{Ce}(\mathrm{IV}), \mathrm{V}(\mathrm{V})$, and iodate interfere severely in the determination of Fe(III). However, interference of these ions could be obviated by use of appropriate masking agents in analysis of the samples.

\section{Analytical performance}

A linear calibration graph was obtained for 1.5 to $9 \mu \mathrm{g}$ iron(III) in a final volume of $10 \mathrm{~mL}$. The detection limit $(\mathrm{DL}=3.3 \mathrm{\sigma} / \mathrm{S})$ and quantitation limit $(\mathrm{QL}=10 \mathrm{\sigma} / \mathrm{S})$ [where ' $\sigma$ ' is the standard deviation of reagent blank $(n=10)$ and ' $\mathrm{S}$ ' is the slope of calibration curve] of iron determination were found to be 0.01 and $0.04 \mu \mathrm{g} \mathrm{mL}-1$, respectively. The calibration graph has a correlation coefficient of 0.999 . The molar absorptivity, specific absorptivity and the Sandell's sensitivity of the method were found to be $5.6 \times 10^{4} \mathrm{~L} \mathrm{~mol}^{-1} \mathrm{~cm}^{-1}, 1.00 \mathrm{~mL} \mathrm{~g}^{-1} \mathrm{~cm}^{-1}$ and $0.0001 \mu \mathrm{g} \mathrm{cm}^{-2}$, respectively. The reliability of the method was established by analysis of standard solutions of 3,5 and $7 \mu \mathrm{g}$ of iron(III) in a final volume of $10 \mathrm{~mL}$. Ten replicate determinations of each concentration gave relative standard deviations (RSD) of $0.08,0.06$ and $0.04 \%$, respectively.

\section{Applications}

The iron contents of natural water, soil, industrial effluents, plant material, pharmaceutical samples, synthetic mixtures, and aluminium alloys, determined by the proposed method, are shown in Tables 2, 3, 4, and-5, respectively.

\section{Analysis of environmental water samples}

Each filtered (with Whatman No. 40) environmental water sample $(100 \mathrm{~mL})$ evaporated nearly to dryness with $10 \mathrm{~mL}$ of conc. $\mathrm{HNO}_{3}$ in a fume cupboard and was heated with $10 \mathrm{~mL}$ of distilled water in order to dissolve the salts. The solution was then cooled and neutralized with dilute $\mathrm{NH}_{4} \mathrm{OH}$ solution. The resulting solution was then filtered and quantitatively transferred into a $25 \mathrm{~mL}$ calibrated flask

Table 2 Determination of iron in various samples

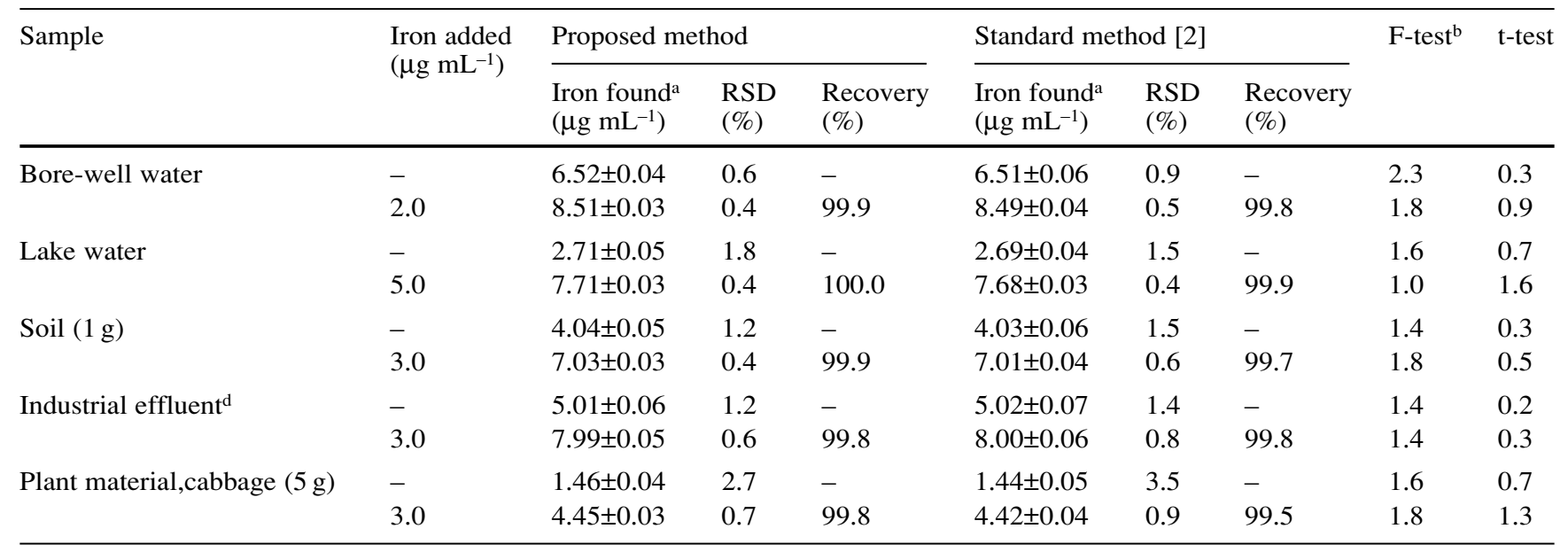

${ }^{\mathrm{a}}$ Mean \pm standard deviation $(\mathrm{n}=5)$

dAfter proper dilution, original concentration of $\mathrm{Fe}(\mathrm{III})$ found

bTabulated F- value for $(4,4)$ degrees of freedom at $P(0.95)$ is 6.39

$1252.5 \mu \mathrm{g} \mathrm{mL}^{-1}$

cTabulated t- value for 8 degrees of freedom at $P(0.95)$ is 2.306 
Table 3 Determination of iron in pharmaceutical preparations

\begin{tabular}{|c|c|c|c|c|c|}
\hline Sample & $\begin{array}{l}\text { Composition of tablet } \\
\text { (w/tablet) }\end{array}$ & $\begin{array}{l}\text { Certified } \\
\text { value of iron } \\
(\mathrm{mg} / \text { tablet })\end{array}$ & $\begin{array}{l}\text { Iron found } \\
(\mathrm{mg} / \text { tablet })\end{array}$ & $\begin{array}{l}\text { Recovery } \\
(\%)\end{array}$ & $\mathrm{t}$-test ${ }^{\mathrm{b}}$ \\
\hline $\begin{array}{l}\text { Iron and folic acid tablets }{ }^{c} \\
\text { [Micro Labs Ltd., India] }\end{array}$ & $\begin{array}{l}\text { Dried ferrous sulfate IP } 200 \mathrm{mg} \text { (approximately } \\
\text { equivalent to ferrous iron } 60 \mathrm{mg} \text { ) folic acid IP } \\
0.5 \mathrm{mg}[0.350 \mathrm{~g}]\end{array}$ & 60.0 & $59.8 \pm 0.03$ & 99.7 & 1.5 \\
\hline $\begin{array}{l}\text { ToFe, chewable iron tablet } \\
\text { [Alkem Laboratories Ltd., } \\
\text { India] }\end{array}$ & $\begin{array}{l}\text { Iron(III) hydroxide polysucrose complex equi- } \\
\text { valent to elemental iron } 100 \mathrm{mg} \text {, folic acid IP } \\
1 \mathrm{mg}[0.350 \mathrm{~g}]\end{array}$ & 100.0 & $99.9 \pm 0.04$ & 99.9 & 0.6 \\
\hline $\begin{array}{l}\text { Ferium, chewable tablet } \\
\text { [Emcure Pharmaceuticals } \\
\text { Ltd., India] }\end{array}$ & $\begin{array}{l}\text { Iron(III) hydroxide polymaltose complex equi- } \\
\text { valent to elemental iron } 100 \mathrm{mg} \text {, folic acid } \\
\mathrm{IP}=350 \mu \mathrm{g}[0.400 \mathrm{~g}]\end{array}$ & 100.0 & $100.02 \pm 0.04$ & 100.02 & 1.1 \\
\hline $\begin{array}{l}\text { Irex-12 } 12^{c} \text { [Micro Labs Ltd., } \\
\text { India] }\end{array}$ & $\begin{array}{l}\text { Ferrous flumarate IP } 350 \mathrm{mg} \text { equivalent to } \\
\text { elemental iron } 115 \mathrm{mg} \text {, folic acid } 1.5 \mathrm{mg} \\
\text { cyanocobalamin } 15 \mu \mathrm{g} \text { (as cyanocobalamin } 0.1 \% \\
\text { in gelatin }[0.450 \mathrm{~g}]\end{array}$ & 115.0 & $115.0 \pm 0.06$ & 100.0 & 0.0 \\
\hline
\end{tabular}

${ }^{\mathrm{a}}$ Mean \pm standard deviation $(\mathrm{n}=5)$

${ }^{b}$ Tabulated t-value for 4 degrees of freedom at $P(0.95)$ is 2.776

${ }^{c}$ Analyzed after converting $\mathrm{Fe}(\mathrm{II})$ to $\mathrm{Fe}(\mathrm{III})$

Table 4 Analysis of synthetic mixtures containing iron(III)

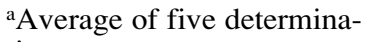
tions

${ }^{\mathrm{b}}$ The measure of precision is the SD

Table 5 Determination of iron in aluminium alloy samples

${ }^{\mathrm{a}}$ Mean \pm standard deviation $(\mathrm{n}=5)$

${ }^{\mathrm{b}}$ Tabulated t-value for $4 \mathrm{de}-$ grees of freedom at $\mathrm{P}(0.95)$ is 2.776

\begin{tabular}{|c|c|c|c|c|c|}
\hline \multirow[t]{2}{*}{ Sample } & \multirow{2}{*}{\multicolumn{2}{|c|}{$\begin{array}{l}\text { Composition of mixture } \\
\left(\mu \mathrm{g} \mathrm{mL}^{-1}\right)\end{array}$}} & \multicolumn{2}{|l|}{ Iron(III) } & \multirow{2}{*}{$\begin{array}{l}\text { Recovery } \\
\pm \mathrm{SD}^{\mathrm{b}} \\
(\%)\end{array}$} \\
\hline & & & \multirow{2}{*}{$\begin{array}{l}\begin{array}{l}\text { Added } \\
\left(\mu \mathrm{g} \mathrm{mL}^{-1}\right)\end{array} \\
0.40 \\
0.80\end{array}$} & $\begin{array}{l}\text { Found }^{\mathrm{a}} \\
\left(\mu \mathrm{g} \mathrm{mL}^{-1}\right)\end{array}$ & \\
\hline A & \multicolumn{2}{|l|}{$\mathrm{Fe}(\mathrm{III})$} & & $\begin{array}{l}0.40 \\
0.79\end{array}$ & $\begin{array}{r}100.0 \pm 0.0 \\
98.8 \pm 0.5\end{array}$ \\
\hline B & \multicolumn{2}{|c|}{$\mathrm{As}$ in $\mathrm{A}+\mathrm{Ca}^{2+}(20)+\mathrm{Cu}^{2+}(2.0)+\mathrm{Al}^{3+}(0.5)$} & $\begin{array}{l}0.40 \\
0.80\end{array}$ & $\begin{array}{l}0.39 \\
0.81\end{array}$ & $\begin{array}{r}98.0 \pm 0.7 \\
101.2 \pm 0.6\end{array}$ \\
\hline $\mathrm{C}$ & \multicolumn{2}{|c|}{ As in $\mathrm{A}+\mathrm{Ni}^{2+}(6.0)+\mathrm{Cr}^{\mathrm{VI}}(0.5)+\mathrm{NO}_{3}^{-}(25)$} & $\begin{array}{l}0.40 \\
0.80\end{array}$ & $\begin{array}{l}0.41 \\
0.80\end{array}$ & $\begin{array}{l}102.5 \pm 0.7 \\
100.0 \pm 0.0\end{array}$ \\
\hline $\mathrm{D}$ & \multicolumn{2}{|c|}{ As in $\mathrm{A}+\mathrm{Mn}^{2+}(5)+\mathrm{Ni}^{2+}(5)$} & $\begin{array}{l}0.40 \\
0.80\end{array}$ & $\begin{array}{l}0.40 \\
0.81\end{array}$ & $\begin{array}{l}100.0 \pm 0.0 \\
101.2 \pm 0.5\end{array}$ \\
\hline $\mathrm{E}$ & \multicolumn{2}{|c|}{$\mathrm{As}$ in $\mathrm{A}+\mathrm{Ca}^{2+}(20)+\mathrm{Zn}^{2+}(20)+\mathrm{Mg}^{2+}(20)$} & $\begin{array}{l}0.40 \\
0.80\end{array}$ & $\begin{array}{l}0.39 \\
0.80\end{array}$ & $\begin{array}{r}98.0 \pm 0.4 \\
100.0 \pm 0.0\end{array}$ \\
\hline $\begin{array}{l}\text { Sample } \\
(\mathrm{w} / \mathrm{v})\end{array}$ & & $\begin{array}{l}\text { Certified iron } \\
\text { content }(\%)\end{array}$ & $\begin{array}{l}\text { Iron } \\
\text { found }^{\mathrm{a}}\end{array}$ & $\begin{array}{l}\mathrm{RSD} \\
(\%)\end{array}$ & $\mathrm{t}$-test ${ }^{\mathrm{b}}$ \\
\hline $\begin{array}{l}\text { BCS No. } \\
{[\mathrm{Mg} 10.7}\end{array}$ & $\begin{array}{l}262 / 1(0.1 \mathrm{~g} / 100 \mathrm{~mL}) \\
\%, \mathrm{Cu} 0.039 \%, \mathrm{Ni} 0.07 \%]\end{array}$ & 0.2 & $0.199 \pm 0.002$ & 1.00 & 1.12 \\
\hline $\begin{array}{l}\text { BCS No. } \\
{[\text { Si } 2.0 \%}\end{array}$ & $\begin{array}{l}380(0.05 \mathrm{~g} / 100 \mathrm{~mL}) \\
\text { Ni } 0.011 \%, \mathrm{Cu} 0.900 \%]\end{array}$ & 1.15 & $1.148 \pm 0.005$ & 0.44 & 0.89 \\
\hline
\end{tabular}

and made up to the mark with distilled water. An aliquot $(\leq 2 \mathrm{~mL})$ of this pre-concentrated water sample was pipetted out into a $10 \mathrm{~mL}$ calibrated flask and the iron(III) content was determined by the proposed method.

\section{Analysis of soil sample}

An air-dried homogenized soil sample (100 g) was weighed accurately and placed in a $100 \mathrm{~mL}$ Kjeldhal flask. The sample was digested in the presence of an oxidizing agent, following the method recommended by Jackson [24]. The content of flask was filtered through Whatman
No.40 filter paper into a $25 \mathrm{~mL}$ calibrated flask and neutralized with dilute ammonia. It was then diluted up to the mark with distilled water. Suitable aliquots $(\leq 2 \mathrm{~mL})$ of this sample was then analyzed for iron(III) content by the proposed procedure.

\section{Analysis of industrial effluents}

The industrial effluents (electroplating) from post-coagulation settling basin were collected, and the volume of the sample was adjusted for the dynamic linear range by proper dilution with distilled water. Suitable aliquots $(1 \mathrm{~mL})$ of 
sample solution were analyzed according to the procedure for iron(III).

\section{Analysis of plant material}

A sample of plant material $(5 \mathrm{~g})$ was digested with $10 \mathrm{~mL}$ conc. $\mathrm{HNO}_{3}$ for $20 \mathrm{~min}$. After cooling, $0.5 \mathrm{~mL}$ perchloric acid was added and heating was continued for another $10 \mathrm{~min}$. To the cooled residue, $10 \mathrm{~mL}$ water and $5 \mathrm{~mL}$ dilute $\mathrm{H}_{2} \mathrm{O}_{2}$ were added and boiled for $10 \mathrm{~min}$ to convert $\mathrm{Fe}(\mathrm{II})$ to $\mathrm{Fe}(\mathrm{III})$ [12]. Heating was further continued to expel remaining $\mathrm{H}_{2} \mathrm{O}_{2}$, if any. The solution was cooled, and neutralized with dilute $\mathrm{NH}_{4} \mathrm{OH}$ solution and diluted to $50 \mathrm{~mL}$. An aliquot of this solution $(\leq 2 \mathrm{~mL})$ was analyzed for iron(III) according to the proposed procedure.

In all the above analyses (Table 2) parallel determination were carried out using the standard phenanthroline method [2]. A statistical analysis of the results by the F- and t-tests showed no significant difference in the proposed and standard method. This shows the precision and accuracy of the proposed method. The reliability of the method for analysis of real samples was checked by recovery experiments, which gave quantitative results with appropriate reproducibility.

\section{Analysis of pharmaceutical samples}

Samples of finely ground iron tablets of known weight were treated with $5 \mathrm{~mL}$ conc. nitric acid, and the resulting mixture were evaporated to dryness. The residue was leached with $5 \mathrm{~mL} 0.5 \mathrm{~mol} \mathrm{~L}^{-1} \mathrm{H}_{2} \mathrm{SO}_{4}$ [23]. The solution was boiled with dilute $\mathrm{H}_{2} \mathrm{O}_{2}$ for $10 \mathrm{~min}$ [for tablets containing $\mathrm{Fe}(\mathrm{II})]$, heating was continued for further $5 \mathrm{~min}$ to boil off any excess of $\mathrm{H}_{2} \mathrm{O}_{2}$. The solution was cooled, neutralized with dilute ammonia and diluted to known volume with water. A suitable aliquots of made up solution were analyzed according to the suggested procedure for $\mathrm{Fe}(\mathrm{III})$ [Table 3]. The results indicate the reliability of the method in recovering iron from these samples.

\section{Analysis of synthetic mixtures}

Several synthetic mixtures of varying compositions containing iron and diverse ions of known concentrations were prepared and $\mathrm{Fe}(\mathrm{III})$ was determined by the present method. The results were found to be highly reproducible. Accurate recoveries were achieved in all solutions (Table 4).

\section{Analysis of aluminum alloys}

Aluminum alloys were brought into solution by the addition of $15 \mathrm{~mL} \mathrm{1:1} \mathrm{hydrochloric} \mathrm{acid} \mathrm{and} 3 \mathrm{~mL}$ conc. nitric acid, and heated until the solution was clear [25]. The solution was made up to a known volume, suitable aliquots of this sample solution were analyzed for Fe(III) using the proposed procedure. The results summarized in Table 5 clearly shows that the developed method works satisfactorily for analysis of iron(III) in alloys.

\section{Conclusions}

The developed method for the determination of iron(III) is simple, inexpensive, rapid, and sensitive (molar absorptivity $5.6 \times 10^{4} \mathrm{~L} \mathrm{~mol}^{-1} \mathrm{~cm}^{-1}$ ) in comparison with previously reported procedures $[12,13,14,15,16,17,18,19$, $20,21,22]$. The added advantage of this method in comparison with AAS and ICP-emission spectrometry methods is its simplicity, low cost, reliability and applicability to field determination of iron. The new method has been successfully applied to the determination of iron in real as well as in synthetic matrices.

Acknowledgements One of the authors (T.N. Kiran Kumar) gratefully acknowledges University Grants Commission, New Delhi, and Department of Collegiate Education, Government of Karnataka, for award of a Teacher Fellowship.

\section{References}

1. Abbasi SA (1988) Anal Lett 21(3) 491-505

2. APHA (1995) Standard methods for examination of water and wastewater, 19th edn. American Public Health Association, Washington DC, pp 3-67

3. B.Welz (1985) Atomic absorption spectroscopy. VCH, Amsterdam, The Netherlands

4. Van Loon JC (1985) Selected methods of trace metal analysis. Wiley, New York

5. Koshy VJ, Garg VN (1986) J Scient Industr Res 45:294-296

6. Yasmeen F, Aleen R, Anwar J (2000) J Chem Soc Pakistan 22:99-97

7. Canfranc E, Abarca A, Sierra I, Marina ML (2001) J Pharmaceut Biomed Anal 25:103-108

8. Babu DR, Naidu PR (1991) Talanta 38:175-179

9. Yamini Y, Amiri N (2001) J AOAC Int 84:713-717

10. Arya SP, Mahajan M, Jain P (2000) Indian J Chem 39 Sect A: 552-553

11. Sarma LS, Ramesh GN, Kumar CJ, Reddy AV (2000) J Indian Chem Soc 77:405-406

12. Marczenko Z (1986), Separation and spectrophotometric determination of elements, 2nd edn. Ellis Harwood, UK, p 330

13. Kopacek J, Borovec J, Hejzlar J, Porcal P (2001) Commun Soil Sci Plant Anal 32:1431-1443

14. Hashem EY (2001) J AOAC Int 84:537-545

15. Patel KS, Shukla A, Goswami A, Chandravanshi SK, Hoffmann P (2001) Fresenius J Anal Chem 369:530-534

16. Tiwari S, Khan S, Mohabey H (2001) Asian J Chem 13: 350-352

17. Malik AK (2000) J Agr Food Chem 48:5808-5811

18. Areis MCD, Avila-Terra LHS, I.Gaubeur, Suarez-Iha MEV (2001) Spectrosc Lett 34:289-300

19. Tarafdar PK, Sardana A Chem Anal (Warsaw) 45 (2000) $145-151$

20. Tarafdar PK, Balasubramanian N (1999) Chem Anal (Warsaw) 44:731-737

21. Grabaric Z, Bokic L, Stefanovic B (1999) J AOAC Int 82: 683-688

22. Benmansour K, Nasser TAK, Mansri A (1998) Quim Anal 17: 213-216

23. Sundaramurthi NM, Shinde VM (1991) Analyst 116:541-544

24. Jackson ML (1965) Soil Chemical Analysis. Prentice-Hall, Englewood Cliffs, p 326

25. Snell FD (1978) Photometric and fluorimetric methods of analysis, Part I. Wiley, New York, p 145 